\title{
PENGARUH REPUTASI AUDITOR DAN MEKANISME CORPORATE GOVERNANCE TERHADAP INTEGRITAS LAPORAN (Studi Empiris Pada Perusahaan Manufaktur yang Terdaftar di Bursa Efek Indonesia Periode 2008-2010)
}

Fitri Damayanti

Rochmi

UIN Syarif Hidayatullah Jakarta

\begin{abstract}
$A B S T R A C T$
This study aims to obtain empirical evidence about the effect of auditor reputation, corporate governance mechanism (independent commissioner managerial ownership, institutional ownership) to integrity of financial statement at the manufacturer companies in Indonesia. Integrity of financial statement define as how far a financial statement disclosure shows truth and honest information. Independent variables used in this study were reputation auditor and corporate governance mechanism was analyzed by independent commissioner managerial ownership, institutional ownership. Dependent variable used in this study is integrity of financial statement was analyzed by conservatism. Study's sample was manufacturer companies listed in Indonesia Stock Exchange (IDX) period among 2008-2010. Data was collected by purposive sampling method. Total 56 manufacturer companies were taken as study's sample. The method of analysis of this research used multiple regression. The results of this research showed that reputation auditor and independent commissioner had significant effect to integrity of financial statement. Meanwbile, Institutional ownership and managerial ownership had not significant effect to integrity of financial statement.
\end{abstract}

Keywords: Integrity of financial statement, Auditor Reputation, Corporate Governance Mechanism.

\section{PENDAHULUAN}

Laporan keuangan merupakan salah satu sumber informasi yang secara formal wajib dipublikasikan sebagai sarana pertanggungjawaban pihak manajemen terhadap pengelolaan sumber daya pemilik. Publikasi laporan keuangan sebagai produk informasi akuntansi yang dihasilkan perusahaan, tidak terlepas dari proses penyusunannya. Kebijakan akuntansi dan metode akuntansi yang digunakan dalam proses penyusunan laporan keuangan merupakan unsur yang sangat vital. Menurut survey Pricewaterbouse Coopers pada tahun 1999 terhadap investor-investor internasional menunjukan bahwa Indonesia dinilai sebagai salah satu yang terburuk dalam bidang standar-standar akuntansi, pertanggungjawaban terhadap para pemegang saham, standar-standar pengungkapan dan transparansi serta prosesproses kepengurusan perusahaan (FCGI, 2002:88) dalam Pratolo (2008:2).

Untuk mengukur integritas informasi laporan keuangan, Standar Akuntansi Keuangan (SAK, 2004 ) menetapkan karakteristik kualitatif yang harus dimiliki informasi akuntansi agar dapat digunakan dalam proses pengambilan keputusan. Hedriksen and Van Breda (2000) dalam jama'an (2008:16) mengemukakan beberapa karakteristik kualitatif dalam laporan keuangan yaitu cost and benefit, Relevance, Reliability, Comparability, dan Materiality. 
Informasi memiliki kualitas andal jika bebas dari pengertian yang menyesatkan, kesalahan material, dan dapat di andalkan pemakainya sebagai penyajian yang tulus atau jujur (faithful representation) dari yang seharusnya disajikan atau yang secara wajar diharapkan dapat disajikan (SAK, 2004). Informasi akuntansi yang tidak reliability menyebabkan jatuhnya perusahaan- perusahaan raksasa dunia pada awal dekade 2000an akibat dari skandal kasus-kasus hukum manipulasi akuntansi yang melibatkan perusahaan besar, karena melakukan tindakan earnings management, telah memunculkan beberapa kasus skandal pelaporan akuntansi yang secara luas diketahui, antara lain Enron, WorldCom dan mayoritas perusahaan lain di Amerika Serikat (Cornett et al., 2006), (Siswanto \& Aldridge, 2005) dalam (Jama’an, 2008:16).

Dalam kasus Enron misalnya, satu dampak yang sangat jelas yaitu kerugian yang ditanggung para investor dari ambruknya nilai saham yang sangat dramatis dari harga per saham US\$ 30 menjadi hanya US\$ 10 dalam waktu dua minggu karena menyembunyikan hutang dan mendongkrak laba lebih dari $\$ 1$ milyar, serta menyogok pejabat asing untuk memenangkan kontrak di luar Amerika. Pertanyaan yang kemudian muncul adalah mengapa suatu perusahaan kelas dunia dapat mengalami hal yang sangat tragis dengan mendeklarasikan bangkrut justru setelah hasil audit keuangan perusahaannya dinyatakan “wajar tanpa pengecualian” (Alijoyo, 2003), dalam Jama’an, (2008:17). Berikut ini akan di paparkan 10 skandal akuntansi besar di dunia.

Tabel 1

Sepuluh Skandal Akuntansi Besar di Dunia

\begin{tabular}{|c|l|l|}
\hline No & Nama Perusahaan & \multicolumn{1}{c|}{ Tuduhan Kasus Kecurangan } \\
\hline 1 & $\begin{array}{l}\text { Bank of Credit and } \\
\text { Commerce } \\
\text { International } \\
\text { (BCCI) }\end{array}$ & $\begin{array}{l}\text { Salah satu skandal terbesar dalam sejarah } \\
\text { keuangan dengan kecurangan \$20 milyar lebih. Lebih dari } \\
\$ 13 \text { milyar dana unaccounted, penyuapan, mendukung } \\
\text { terorisme, money laundering, penyeludupan, penjualan } \\
\text { teknologi nuklir, dan lain-lain. }\end{array}$ \\
\hline 2 & Enron Corporation & $\begin{array}{l}\text { Menyembunyikan hutang dan mendongkrak } \\
\text { laba lebih dari \$1 milyar, menyogok pejabat asing untuk } \\
\text { memenangkan kontrak di luar Amerika. }\end{array}$ \\
\hline 3 & World Com & $\begin{array}{l}\text { Cash flow didongkrak \$3,8 milyar dengan } \\
\text { mencatat operating expenses dengan capital expenses. }\end{array}$ \\
\hline 5 & Tyco International & $\begin{array}{l}\text { CEO (Dennis Kozlowski) dan mantan CFO } \\
\text { (Mark H. Swartz) dituduh melakukan pencurian sebesar } \\
\text { \$600 juta dari perusahaan pada tahun 2002. }\end{array}$ \\
\hline 6 & Waste Management, Inc & $\begin{array}{l}\text { Melambungkan keuntungan sebesar \$2 } \\
\text { milyar lebih dari 5 tahun periode. }\end{array}$ \\
\hline $\begin{array}{l}\text { Laba yang meningkat sebesar \$17 milyar } \\
\text { tengan menambah masa manfaat penyusutan untuk aset }\end{array}$ \\
\hline
\end{tabular}




\begin{tabular}{|c|l|l|}
\hline No & Nama Perusahaan & \multicolumn{1}{|c|}{ Tuduhan Kasus Kecurangan } \\
\hline 7 & Parmalat & $\begin{array}{l}\text { Total hutang perusahaan lebih dari dua kali } \\
\text { lipat yang tercatat di neraca. Pemalsuan dan } \\
\text { kebangkrutan adalah tuduhan lainnya. }\end{array}$ \\
\hline 8 & $\begin{array}{l}\text { Health South } \\
\text { Corporation }\end{array}$ & $\begin{array}{l}\text { Pendapatan perusahaan overstated sebanyak } \\
4700 \text { persen dan \$14 milyar dilambungkan untuk } \\
\text { memenuhi harapan investor. }\end{array}$ \\
\hline 9 & $\begin{array}{l}\text { American } \\
\text { International } \\
\text { Group (AIG) }\end{array}$ & $\begin{array}{l}\text { Perusahaan mempertahankan perjanjian kecurangan } \\
\text { payoff menguntungkan. Melakukan ken an } \\
\text { permohonan penawaran untuk kontrak asuransi dan } \\
\text { melambungkan posisi keuangan sebesar \$2,7 Milyar } \\
\text { pada tahun }\end{array}$ \\
\hline 10 & $\begin{array}{l}\text { Satyam } \\
\text { Computer } \\
\text { Services }\end{array}$ & $\begin{array}{l}\text { Melambungkan nilai piutang (overstated } \\
\text { rendah dari yang seharusnya sebesar \$250 milyar yang } \\
\text { dilakukan untuk kepentingan Ramalinga Raju (pendiri dan } \\
\text { pemimpin Satyam Computer Services) }\end{array}$ \\
\hline
\end{tabular}

Sumber: http://bizcovering.com/history/10-major-accounting-scandals/

Di Indonesia juga pernah terjadi hal yang sama, salah satunya yaitu pada kasus PT. Kimia Farma Tbk dan PT. Great River International Tbk, dimana terdapat overstated pada laba bersih per 31 Desember 2001 di PT. Kimia Farma, serta pada PT. Great River terjadi kelebihan pencatatan atau overstatement penyajian account penjualan dan piutang dalam laporan keuangan tahun 2003. Berdasarkan kasus-kasus skandal keuangan dan penelitian yang ada membuktikan kegagalan integritas laporan keuangan untuk memenuhi kebutuhan informasi para pengguna laporan. Laba sebagai bagian dari laporan keuangan tidak menyajikan fakta yang sebenarnya tentang kondisi ekonomi perusahaan, sehingga laba yang diharapkan dapat memberikan informasi untuk mendukung pengambilan keputusan menjadi diragukan kualitasnya (Gideon, 2005:173)

Integritas suatu laporan keuangan secara intuitif dapat diukur melalui dua cara, yaitu diukur dengan konservatisme serta keberadaan manipulasi laporan keuangan yang biasanya diukur dengan manajemen laba. Beberapa peneliti menyatakan bahwa auditor lebih menyukai pelaporan yang konservatif Basu (1997), De Fond (1992), dan Subramanyam (1996) dalam Jama'an (2008:16).

Konservatisme merupakan prinsip akuntansi yang jika diterapkan akan menghasilkan angka-angka laba dan aset cenderung rendah, serta angka- angka biaya dan utang cenderung tinggi. Kecenderungan seperti itu terjadi karena konservatisme menganut prinsip memperlambat pengakuan pendapatan serta mempercepat pengakuan biaya. Akibatnya, laba yang dilaporkan cenderung terlalu rendah (understatement). Sampai saat ini masih terjadi pertentangan mengenai manfaat konservatisme dalam laporan keuangan. Sebagian peneliti 
berpendapat bahwa laba yang dihasilkan dari metode yang konservatif kurang berkualitas, tidak relevan, dan tidak bermanfaat, sedangkan sebagian lainnya berpendapat bahwa laba konservatif, yang disusun menggunakan prinsip akuntansi yang konservatif mencerminkan laba minimal yang dapat diperoleh perusahaan sehingga laba yang disusun dengan metoda yang konservatif merupakan laba yang tidak "dibesar-besarkan" (overstate) nilainya, sehingga dapat dianggap sebagai laba yang berkualitas (Dewi, 2004:209).

SAK sendiri mencerminkan kecenderung pada akuntansi konservatif, dalam beberapa PSAK dapat dilihat pada PSAK No. 13 (1994): (1) Akuntansi untuk Investasi, paragraf 38 menyatakan bahwa investasi yang diklasifikasikan sebagai aktiva lancar harus dicatat dalam neraca pada nilai terendah antara biaya dan nilai pasar; (2) PSAK No. 14 (1994): Akuntansi untuk Persediaan, paragraf 38 menyatakan bahwa persediaan diukur berdasarkan biaya atau nilai realisasian bersih mana yang lebih rendah; (3) PSAK No. 19 (Revisi 2000): Aktiva Tidak Berwujud, paragraf 36 menyatakan bahwa perusahaan tidak boleh mengakui aktiva tidak berujud yang timbul dari riset (atau dari tahap riset pada suatu proyek intern). Pengeluaran untuk riset (atau tahap riset pada suatu proyek intern) diakui sebagai beban pada saat terjadinya. (4) Paragraf 39 menyatakan suatu aktiva tidak berwujud yang timbul dari pengembangan (atau dari tahap pengembangan pada suatu proyek intern) diakui jika, dan hanya jika, perusahaan dapat memenuhi enam kriteria tertentu; (5) PSAK No. 48 (1998): Penurunan Nilai Aktiva, paragraf 41 menyatakan jika nilai yang diperoleh kembali dari suatu aktiva lebih kecil dari nilai tercatatnya, nilai tercatat aktiva harus diturunkan menjadi sebesar nilai yang dapat diperoleh kembali. Penurunan tersebut merupakan rugi penurunan nilai aktiva dan harus segera diakui sebagai beban pada laporan laba rugi (Lo, 2005:397).

Corporate governance merupakan tata kelola perusahaan yang menjelaskan hubungan antara berbagai partisipan dalam perusahaan yang menentukan arah kinerja perusahaan. Isu mengenai corporate governance mulai mengemuka, khususnya di Indonesia pada tahun 1998 ketika Indonesia mengalami krisis yang berkepanjangan. Banyak pihak yang mengatakan lamanya proses perbaikan di Indonesia disebabkan oleh sangat lemahnya corporate governance yang diterapkan dalam perusahaan di Indonesia. Sejak saat itu, baik pemerintah maupun investor mulai memberikan perhatian yang cukup signifikan dalam praktek corporate governance.

Penelitian yang dilakukan oleh Jama'an (2008:84), mekanisme corporate governance yang diukur dengan kepemilikan institusional, komisaris independen dan komite audit serta kualitas audit yang diukur dengan spesialisasi jasa auditor dapat mempengaruhi secara signifikan terhadap integritas laporan keuangan. Berbeda dengan penelitian yang dilakukan oleh Guna dan Herawaty (2010:65) yang meneliti pengaruh mekanisme corporate governance, 
independensi auditor, kualitas audit dan faktor lainnya terhadap manajemen laba menemukan hasil bahwa leverage, kualitas audit dan profitabilitas berpengaruh terhadap manajemen laba. Sedangkan kepemilikan institusional, kepemilikan manajemen, komite audit, komisaris independen, independensi auditor dan ukuran perusahaan tidak berpengaruh terhadap manajemen laba.

Selain dari pihak perusahaan, auditor external juga harus turut bertanggung jawab terhadap merebaknya kasus-kasus manipulasi akuntansi seperti ini. Posisi akuntan publik sebagai pihak independen yang memberikan opini kewajaran terhadap laporan keuangan serta profesi auditor yang merupakan profesi kepercayaan masyarakat juga mulai banyak dipertanyakan apalagi setelah didukung oleh bukti semakin meningkatnya tuntutan hukum terhadap kantor akuntan. Padahal profesi akuntan mempunyai peranan penting dalam penyediaan informasi keuangan yang handal bagi pemerintah, investor, kreditor, pemegang saham, karyawan, debitur, juga bagi masyarakat dan pihak-pihak lain yang berkepentingan.

Penting bagi pemakai laporan keuangan untuk memandang KAP sebagai pihak yang independen dan kompeten, karena akan mempengaruhi berharga atau tidaknya jasa yang telah diberikan oleh KAP kepada pemakai. Setiap auditor harus mempertahankan integritas dan objektivitas dalam menjalankan tugas dengan bertindak jujur, tegas, tanpa pretense sehingga auditor dapat bertindak adil, tanpa dipengaruhi tekanan atau permintaan pihak tertentu untuk memenuhi kepentingan pribadinya.

Penelitian yang dilakukan oleh Susiana (2007:17) menunjukan bahwa kualitas audit yang diukur dengan KAP big four dan non big four tidak berpengaruh signifikan terhadap integritas laporan keuangan. Akan tetapi Jamaan (2008:85) dan Guna dan Herawaty (2010:65) menunjukan bahwa reputasi auditor berpengaruh secara signifikan terhadap manajemen laba. Hasil yang signifikan ini disebabkan karena KAP big four memiliki kompetensi, dan pelatihan yang lebih memadai serta memiliki program audit yang lebih kompleks sehingga hasilnya dianggap lebih akurat dibandingkan auditor non big four.

Berdasarkan latar belakang yang telah dipaparkan di atas, maka perumusan masalah atas penelitian ini adalah : (1) Apakah reputasi auditor berpengaruh secara signifikan terhadap integritas laporan keuangan?; (2) Apakah mekanisme corporate governance (komisaris independen, kepemilikan manajerial, kepemilikan institusional) berpengaruh secara signifikan terhadap integritas laporan keuangan? ; (3) Apakah reputasi auditor dan mekanisme corporate governance (komisaris independen, kepemilikan manajerial, kepemilikan institusional) berpengaruh signifikan secara simultan terhadap integritas laporan keuangan?

Integritas informasi laporan keuangan menyangkut keandalan informasi akuntansi yang dihasilkan yaitu kejujuran dalam penyajian, dapat dipercaya, dan netralitas yang antara 
lain dapat dijelaskan Jamaan (2008:31) sebagai berikut:

1. Kejujuran (faithfulness) berarti bahwa terdapat kesesuaian antara satu ukuran keuangan atau penjelasan dan fenomena aktivitas ekonomi yang diukur atau dijelaskan. Dalam akuntansi, sumber-sumber ekonomi, kewajiban dan kejadian-kejadian yang membawa perubahan sumber- sumber dan kewajiban-kewajiban dinyatakan dalam laporan keuangan.

2. Dapat dipercaya (Reliability) berarti bahwa seorang pengguna dapat menggantungkan atau memiliki keyakinan pada informasi yang dilaporkan. Informasi akuntansi dipertimbangkan dapat dipercaya (reliability) jika informasi secara nyata menyatakan apa yang dimaksud, apa yang diungkapkan dan dapat diuji kebenaranya.

3. Netral (Neutrality) berarti bahwa informasi akuntansi harus netral, atau tidak memihak yang memberikan dampak pada perilaku para pengguna informasi. Oleh karena informasi akuntansi memberi pengaruh terhadap lingkungannya, maka dipandang penting bahwa informasi akuntansi harus bersifat netral atau tidak bias. Sementara, laporan keuangan terdukung pada satu konsekuensi ekonomi umum, seperti alokasi sumber kekayaan, oleh karenanya informasi harus bersifat netral dari segala konsekuensi lainnya.

Laporan keuangan menjadi alat utama bagi perusahaan untuk menyampaikan informasi keuangan mengenai pertanggungjawaban pihak manajemen (Schipper dan Vincent, 2003). Sedangkan (SAK, 2004) menyebutkan bahwa tujuan laporan keuangan adalah menyediakan informasi yang menyangkut posisi keuangan, kinerja, serta perubahan posisi keuangan suatu perusahaan yang bermanfaat bagi sejumlah besar pemakai dalam pengambilan keputusan ekonomi, Jamaan (2008:33).

Ukuran integritas laporan keuangan secara intuitif dapat dibedakan menjadi dua, yaitu diukur dengan konservatisme serta keberadaan manipulasi laporan keuangan yang biasanya diukur dengan manajemen laba. Beberapa peneliti menyatakan bahwa auditor lebih menyukai pelaporan yang konservatif DeFond dan Subramanyam (1998) dalam Susiana (2007:10).

Achmad Syakhroza (2002) dalam OECD (2006:7) mendefinisikan Corporate Governance sebagai berikut.

"Corporate governance adalah suatu sistim yang dipakai "Board" untuk mengarahkan dan mengendalikan serta mengawasi (directing, controlling, and supervising) pengelolaan sumber daya organisasi secara efisien, efektif, ekonomis, dan produktif - E3P dengan prinsip-prinsip transparan, accountable, responsible, independent, dan fairness - tarif - dalam rangka mencapai tujuan organisasi".

Definisi Corporate Governance sesuai dengan Surat Keputusan Menteri BUMN No Kep-117/M-MBU/2002 tanggal 31 Juli 2002 tentang penerapan praktik GCG pada 
BUMN (OECD, 2006:8) adalah:

"Suatu proses dan struktur yang digunakan oleh organ BUMN untuk, meningkatkan keberhasilan usaha dan akuntabilitas perusabaan guna mewujudkan nilai pemegang sabam dalam jangka panjang dengan tetap memperbatikan kepentingan stakeholder lainnya, berlandaskan peraturan perundangan dan nilai-nilai etika".

Definisi ini menekankan pada keberhasilan usaha dengan memperhatikan akuntabilitas yang berlandaskan pada peraturan perundangan dan nilai-nilai etika serta memperhatikan stakeholders yang tujuan jangka panjangnya adalah untuk mewujudkan dan meningkatkan nilai pemegang saham. Corporate governance merupakan suatu mekanisme yang dapat mengendalikan (mengatur) perilaku stakeholders dengan demikian corporate governance dapat mempengaruhi pilihan manajemen dalam menerapkan prinsip akuntansi yang terkait dengan prinsip konservatisma. Ball et al (2000) dalam Wibowo (2009:15) menyatakan bahwa pilihan terhadap suatu metoda akuntansi yang terkait dengan prinsip konservatisme dipengaruhi juga oleh struktur kepemilikan sebagai salah satu mekanisme corporate governance. Penelitian Widya (2004) dalam Fala (2007:8) menemukan bahwa struktur kepemilikan mempengaruhi pemilihan strategi akuntansi konservatif perusahaan.

Terdapat empat unsur penting dalam corporate governance yang merupakan prinsipprinsip dalam corporate governance, yaitu (FCGI, 2001:15)

1. Faimess (Keadilan)

Menjamin perlindungan hak-hak para pemegang saham, termasuk hak-hak pemegang saham minoritas dan para pemegang saham asing, serta menjamin terlaksananya komitmen dengan para investor. Penetapan tanggung jawab dewan komisaris, direksi, kehadiran komisaris independen dan komite audit serta penyajian informasi (terutama laporan keuangan) dengan pengungkapan penuh merupakan perwujudan dari prinsip keadilan/kewajaran ini.

\section{Transparency (Transparansi)}

Mewajibkan adanya suatu informasi yang terbuka, tepat waktu, serta jelas, dan dapat diperbandingkan yang menyangkut keadaan keuangan, pengelolaan perusahaan, dan kepemilikan perusahaan.

3. Accountability (Akuntabilitas)

Menjelaskan peran dan tanggung jawab, serta mendukung usaha untuk menjamin penyeimbangan kepentingan manajemen dan pemegang saham, sebagaimana yang diawasi oleh dewan komisaris. Realisasi dari prinsip ini dapat berupa pendirian dan pengembangan komite audit yang dapat mendukung terlaksananya fungsi pengawasan dewan komisaris, juga perumusan yang jelas terhadap fungsi audit internal. Khusus untuk bidang akuntansi, penyiapan laporan keuangan yang sesuai dengan standar akuntansi yang berlaku serta diterbitkan tepat waktu juga jelas merupakan perwujudan 
dari prinsip akuntabilitas ini.

4. Responsibility (Pertanggungjawaban)

Memastikan dipatuhinya peraturan serta ketentuan yang berlaku sebagai cerminan dipatuhinya nilai-nilai sosial. Prinsip tanggung jawab ini juga berhubungan dengan kewajiban perusahaan untuk mematuhi semua peraturan dan hukum yang berlaku, termasuk juga prinsip-prinsip yang mengatur tentang penyusunan dan penyampaian laporan keuangan perusahaan.

Penelitian ini bertujuan untuk memperoleh bukti empiris bahwa reputasi auditor dan mekanisme corporate governance (kepemilikan manajerial, kepemilikan institusional dan komisaris independen) mempengaruhi integritas laporan keuangan baik secara parsial maupun simultan.

\section{METODOLOGI PENELITIAN}

\section{a. Populasi dan Sampel Penelitian}

Populasi penelitian ini adalah semua perusahaan yang bergerak dalam bidang Manufaktur yang terdaftar dalam Bursa Efek Indonesia (BEI) tahun 2008-2010. Pemilihan sampel berdasarkan metode purposive sampling yaitu: pengambilan data disesuaikan dengan kriteriakriteria yang telah ditentukan sebelumnya. Adapun sampel yang digunakan dalam penelitian berdasarakan kriteria yaitu: (a) Perusahaan bergerak dalam bidang Manufaktur yang terdaftar diBursa Efek Indonesia (BEI) tahun 2008-2010. (b) Perusahaan menerbitkan laporan keuangan untuk periode 2008 sampai tahun 2010. (c) Laporan keuangan yang digunakan adalah laporan keuangan yang telah diaudit oleh auditor independen.

\section{b. Definisi Operasionalisasi Variabel Penelitian}

1) Konservatisme dengan Ukuran Akrual Diskresioner (Variabel Dependen)

- Variabel dependen dalam penelitian ini adalah Integritas Laporan Keuangan. Pengukuran integritas laporan keuangan menggunakan proxy conservatism. Konservatisme dalam penelitian ini menggunakan ukuran akrual diskresioner model jones yang telah dimodifikasi (Dechow et al., 1995), dengan persamaan berikut:

$\mathrm{TACC}_{\mathrm{it}}=\mathrm{NDACC}_{\mathrm{it}}+\mathrm{DACC}_{\mathrm{it}}$

Dimana:

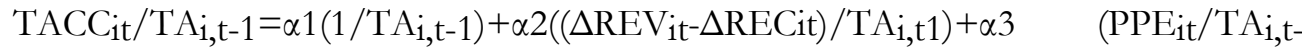

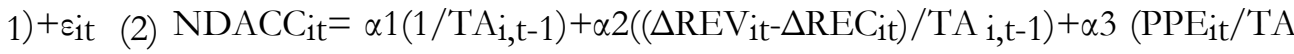
i,t-1 (3) dan untuk memperoleh discretionery accruals adalah:

$\mathrm{DACC}_{i t}=\left(\mathrm{TACC}_{\mathrm{it}} / \mathrm{TA}_{\mathrm{i}, \mathrm{t}-1)-\mathrm{NDACC}_{\mathrm{it}}}\right.$ 
2) Reputasi auditor ( $\left.\mathrm{X}_{1}\right)$ (Variabel Independen)

Untuk meningkatkan kredibilitas dari laporan keuangannya, perusahaan menggunakan jasa Kantor Akuntan Publik (KAP) yang mempunyai reputasi atau nama baik. Hal ini biasanya ditunjukkan dengan kantor akuntan publik yang berafiliasi dengan kantor akuntan publik besar yang berlaku universal yang dikenal dengan Big Four Worldwide Accounting Firm (Big 4). Variabel ini diukur dengan menggunakan variabel dummy. Kategori perusahaan yang menggunakan jasa KAP yang berafiliasi dengan KAP Big 4 diberi nilai 1 dan kategori perusahaan yang menggunakan jasa selain KAP yang berafiliasi dengan KAP Big 4 diberi nilai 0, Herawaty (2008). Adapun KAP big-four yang digunakan dalam penelitian ini adalah: Price Water House Coopers (PWC), Deloitte, Klynveld Peat Marvick Goerdeler (KPMG) International, Ernst and Young (EY) di tahun 2008-2010.

3) Mekanisme Corporate Governance (Variabel Independen)

Adalah suatu aturan main, prosedur dan hubungan yang jelas antara pihak yang mengambil keputusan dengan pihak yang melakukan kontrol trerhadap keputusan tersebut. Mekanisme corporate governance diarahkan untuk menjamin dan mengawasi berjalannya sistem governance dalam sebuah perusahaan. Pada penelitian ini variabel coraporate governance yang digunakan adalah : (1) Komisaris independen $\left(\mathrm{X}_{2}\right)$, Variabel ini diukur dengan variabel dummy, jika perusahaan memiliki komisaris independen diberi nilai 1, jika tidak maka bernilai 0 (Susiana, 2007). (2) Kepemilikan Manajerial (X3), Diukur dengan persentase saham yang dimiliki oleh manajemen yang secara aktif ikut dalam pengambilan keputusan perusahaan (komisaris dan direksi) (Susiana, 2007). (3) Kepemilikan Institusional (X4), Diukur dengan persentase saham yang dimiliki institusi keuangan seperti perusahaan asuransi, bank, dana pensiun dan investment banking (Siregar dan Utama, 2005) dalam Guna dan Herawati (2010).

\section{c. Metode Analisis Data}

Metode Analisis data yang dilakukan adalah : Uji kualitas data dan Uji Asumsi Klasik. Pada penelitian ini penulis menggunakan metode Analisis Regresi Berganda. Metode regresi berganda (multiple regression) dilakukan terhadap model yang diajukan oleh peneliti dengan menggunakan software Eviews 6.0 untuk memprediksi hubungan antara variabel independen dengan variabel dependen. Integritas laporan keuangan yang di proksi-kan dengan menggunakan onservatisme akuntansi yang diukur dengan akrual diskresioner, persamaannya adalah sebagai berikut:

$\mathrm{ACCD}_{i t}=\beta 0+\beta 1 \mathrm{KAPt}_{i t}+\beta 2 \mathrm{KOM}_{i t}+\beta 3 \mathrm{MNJ}_{i t}+\beta 4 \mathrm{INST}_{i t}+\epsilon_{i t}$

Dimana : 
$\mathrm{ACCD}_{\mathrm{it}}=$ Tingkat konservatisme dengan ukuran akrual diskresioner perusahaan i pada waktu t

$\beta 0=$ Konstanta

$\mathrm{KAP}_{\text {it }}=$ Reputasi Audit perusahaan i pada waktu $\mathrm{t}$

$\mathrm{KOM}_{\text {it }}=$ Komisaris independen, yang diukur dengan menggunakan variabel dummy diberi nilai 1 jika perusahaan mempunyai komisaris independen dan 0 jika perusahaan tidak.

MNJit = Persentase kepemilikan saham oleh manajerial pada perusahaan i pada waktu $\mathrm{t}$

INST $_{\text {it }}=$ Persentase kepemilikan saham oleh institusi bank dan atau lembaga keuangan perusahaan i pada waktu $\mathrm{t}$

$€_{i t}=$ Error term

\section{HASIL DAN PEMBAHASAN}

Sebelum pengujian regresi, dilakukan pengujian asumsi multikolinearitas, autokorelasi, normalitas dan heterokedastisitas. Hasil pengujian untuk uji multikolinearitas ini dapat dilihat pada tabel 2 berikut ini :

Tabel 2

Hasil Uji Multikolonearitas

\begin{tabular}{|c|r|c|}
\hline Variabel & Tolerance & VIF \\
\hline Reputasi Auditor & .970 & 1.031 \\
\hline Kepemilikan Institusional & .987 & 1.013 \\
\hline Kepemilikan Manajerial & .957 & 1.045 \\
\hline Komisaris Independen & .983 & 1.017 \\
\hline
\end{tabular}

Sumber: Data diolah

Berdasarkan tabel diatas dapat diketahui bahwa reputasi auditor, kepemilikan institusional, kepemilikan manajerial dan komisaris independen menunjukan nilai tolerance $>0,10$ dan nilai VIF $<10$. Oleh karena itu, dapat dikatakan bahwa variabel independen yang digunakan dalam model regresi pada penelitian ini terbebas dari multikolonieritas atau dapat dipercaya.

Tabel 3

Hasil Uji Autokorelasi

\begin{tabular}{|l|l|l|l|}
\hline R-squared & 0.030052 & Mean dependent var & 0.042503 \\
\hline Adjusted R-squared & 0.006249 & S.D. dependent var & 0.233787 \\
\hline S.E. of regression & 0.233055 & Akaike info criterion & 0.045775 \\
\hline Sum squared resid & 8.853281 & Schwarz criterion & 0.047200 \\
\hline Log likelihood & 8.845095 & Hannan-Quinn criter. & 0.008041 \\
\hline F-statistic & 1.262549 & Durbin-Watson stat & 1.839074 \\
\hline Prob(F-statistic) & 0.286899 & & \\
\hline
\end{tabular}

Sumber : Data diolah 
Pada tabel di atas Durbin-Watson memiliki nilai 1,83 nilai ini berada diantara 1,54 dan 2,46 berarti bahwa dalam data tidak terdapat autokorelasi. Dapat dikatakan bahwa dalam model regresi linear diatas tidak terjadi korelasi antara kesalahan pengganggu pada periode $t$ dengan kesalahan pengganggu pada periode t-1 (sebelumnya).

Tabel 4

Hasil Uji Heteroskedastisitas

\begin{tabular}{|l|l|l|l|}
\hline F-statistic & 1.427938 & Prob. F(12,155) & 0.1585 \\
\hline Obs*R-squared & 16.72361 & Prob. Chi-Square(12) & 0.1603 \\
\hline
\end{tabular}

Sumber : Data diolah

Dari hasil pengujian diatas nilai Obs* R-squared adalah 16,723 dan nilai probabilitasnya adalah 0,160 (lebih besar dari $\alpha=5 \%$ ) maka dapat disimpulkan bahwa model regresi pada penelitian ini bersifat homoskedastisitas atau tidak terjadi heteroskedastisitas.

Tabel 5

Hasil Uji Adjusted R Squared

\begin{tabular}{|c|c|}
\hline R-squared & 0.807634 \\
\hline Adjusted R-squared & 0.702546 \\
\hline
\end{tabular}

Sumber: Data diolah

Berdasarkan tabel di atas, dapat dilihat bahwa nilai adjusted $\mathrm{R}$ square adalah sebesar 0,7025 yang berarti variabilitas variabel dependen yang dapat dijelaskan oleh variabel independen adalah sebesar 70,25\%. Hal ini berarti bahwa sebesar 70,25\% konservatisme dapat dipengaruhi oleh variabel pada penelitian ini yaitu reputasi auditor, kepemilikan institusional, kepemilikan manajerial, dan komisaris independen. Sedangkan sisanya sebesar $29,75 \%$ dipengaruhi oleh variabel lain yang tidak diteliti dalam penelitian ini.

Tabel 6 Hasil Uji Simultan (F)

\begin{tabular}{|l|l|l|l|}
\hline R-squared & 0.807634 & Mean dependent var & 0.042503 \\
\hline Adjusted R-squared & 0.702546 & S.D. dependent var & 0.233787 \\
\hline S.E. of regression & 0.127506 & Akaike info criterion & 1.008859 \\
\hline Sum squared resid & 1.755832 & Schwarz criterion & 0.106843 \\
\hline Log likelihood & 144.7441 & Hannan-Quinn criter. & 0.556053 \\
\hline F-statistic & 7.685275 & Durbin-Watson stat & 2.873519 \\
\hline Prob(F-statistic) & 0.000000 & & \\
\hline
\end{tabular}

Sumber: Data diolah

Pada tabel di atas dapat dilihat bahwa pada nilai $\mathrm{F}$ hitung sebesar 7,685 dan signifikan pada 0,000. Dengan menggunakan tingkat $\alpha=0,05$ maka $\mathrm{H}_{0}$ berhasil ditolak dan $\mathrm{H}_{\mathrm{a}} 5$ diterima atau gagal ditolak. Penolakan $\mathrm{H}_{0}$ dapat dibuktikan dengan hasil perhitungan bahwa nilai sig $(0,000)<$ dari $\alpha=0,05$ sehingga dapat disimpulkan bahwa 
variabel reputasi auditor, kepemilikan institusional, kepemilikan manajerial, dan komisaris independen, secara bersama-sama (simultan) mempengaruhi variabel konservatisme.

\section{Tabel 7}

\section{Hasil Uji t}

Dependent Variable: ACCD? Method: Pooled Least Squares Date: 01/17/12

Time: 02:18

Sample: 20082010

Included observations: 3

Cross-sections included: 56

Total pool (balanced) observations: 168

$\begin{array}{crrrr}\text { Variable } & \text { Coefficient } & \text { Std. Errpr } & \text { t-Statist } \mid c & \text { Prob. } \\ \text { SC } & -0.054980 & 0.111649 & -0.492432 & 0.6234 \\ \text { KAP? } & -0.284304 & 0.113865 & -2.496847 & 0.0140 \\ \text { INST? } & -0.001540 & 0.001696 & -0.907696 & 0.3661 \\ \text { MNJ? } & 0.000546 & 0.010549 & 0.051768 & 0.9588 \\ \text { KOM? } & 0.255486 & 0.124088 & 2.058916 & 0.0419\end{array}$

Sumber: Data diolah

Berdasarkan tabel di atas maka diperoleh persamaan regresi berikut:

\section{$\mathrm{Y}=-0.054980-0.284304 \mathrm{KAP}+0.255486 \mathrm{KOM}+0.000546 \mathrm{MNJ}-0.001540 \mathrm{INST}$}

\section{Reputasi auditor - konservatisme}

Interpretasi dari tabel $7 \mathrm{di}$ atas hasil uji $\mathrm{t}$ menunjukan bahwa variabel reputasi auditor (KAP?) memiliki nilai t hitung sebesar -2,496 dan sig sebesar 0,014. nilai sig sebesar 0,014< $\alpha(0,05)$ hal ini menunjukan bahwa variabel reputasi auditor (KAP?) signifikan pada level 5\% sehingga penelitian ini dapat menolak $\mathrm{H}_{0}$ atau $\mathrm{Ha}_{1}$ diterima yang berarti bahwa variabel reputasi auditor (KAP?) berpengaruh secara signifikan terhadap integritas laporan keuangan.

\section{Komisaris independen - konservatisme}

Variabel komisaris independen (KOM?) memiliki nilai t hitung sebesar 2.058 dan sig sebesar 0.041 . nilai sig sebesar $0.041<\alpha(0,05)$ hal ini menunjukan bahwa variabel komisaris independen (KOM?) signifikan pada level 5\% sehingga penelitian ini tidak dapat menerima $\mathrm{H}_{0}$ atau $\mathrm{Ha}_{2}$ diterima yang berarti bahwa variabel komisaris independen (KOM?) berpengaruh signifikan terhadap integritas laporan keuangan. Dapat dikatakan bahwa, perusahaan yang memiliki komisaris independen membuat laporan keuangan yang disajikan oleh manajemen menjadi lebih konservatif, hal ini dikarenakan fungsi monitoring yang dilakukan oleh pihak independen yang berasal dari luar perusahaan dalam memonitor proses pelaporan keuangan untuk melindungi pemegang saham minoritas dan pihak-pihak lain yang terkait berjalan dengan baik. 


\section{Kepemilikan Manajerial - konservatisme}

Variabel kepemilikan manajerial (MNJ?) memiliki nilai t hitung sebesar 0,051 dan sig sebesar 0,958 . Nilai sig sebesar $0,958>\alpha(0,05)$ hal ini menunjukan bahwa variabel kepemilikan manajerial (MNJ?) tidak signifikan pada level 5\% sehingga penelitian ini dapat menerima $\mathrm{H}_{0}$ atau $\mathrm{Ha} 3$ ditolak yang berarti bahwa variabel kepemilikan manajerial (MNJ?) tidak berpengaruh terhadap integritas laporan keuangan. Hal ini berarti, besarnya kepemilikan saham oleh manajemen tidak membuat laporan keuangan menjadi konservatif. Hasil ini dimungkinkan karena tidak semua manajemen dalam perusahaan yang dijadikan sampel penelitian memiliki saham yang dikelolanya dengan jumlah yang cukup signifikan.

\section{Kepemilikan institusional-konservatisme}

Variabel kepemilikan institusional (INST?) memiliki nilai t hitung sebesar -0,907 dan sig sebesar 0,366. nilai sig sebesar $0,366>\alpha(0,05)$ hal ini menunjukan bahwa variabel kepemilikan institusional (INST?) tidak signifikan pada level 5\% sehingga penelitian ini dapat menerima $\mathrm{H}_{0}$ atau $\mathrm{Ha}_{4}$ ditolak yang berarti bahwa variabel kepemilikan institusional (INST?) tidak berpengaruh terhadap integritas laporan keuangan. Dengan demikian, besarnya kepemilikan saham oleh institusi keuangan dalam suatu perusahaan tidak menjadikan laporan keuangan menjadi konservatif. Hal ini dikarenakan Emiten yang dianalisis memiliki struktur kepemilikan institusi keuangan cukup besar yang mencerminkan kekuasaan, sehingga mempunyai kemampuan untuk melakukan intervensi terhadap jalannya perusahaan dan mengatur proses penyusunan laporan keuangan. Menjadikan manajemen cenderung melakukan manipulasi laba.

\section{KESIMPULAN}

Berdasarkan data yang diperoleh dan hasil pengujian yang telah dilakukan terhadap permasalahan dengan menggunakan model regresi berganda, maka dapat diambil kesimpulan sebagai berikut: Reputasi audit berpengaruh signifikan terhadap integritas laporan keuangan. Hal ini dapat dilihat dari nilai signifikansi sebesar 0,014 nilai ini lebih kecil dari 0,05. Hasil ini mendukung penelitian yang dilakukan oleh Guna dan Herawaty (2010) Herawaty (2008), Jamaan (2008). Akan tetapi, bertentangan dengan hasil penelitian yang dilakukan oleh Susiana (2007).

Komisaris independen berpengaruh signifikan terhadap integritas laporan keuangan. Hal ini dapat dilihat dari signifikansi sebesar 0,041 nilai ini lebih kecil dari 0,05. Hasil ini konsisten dengan penelitian yang dilakukan oleh Gideon (2005), Susiana (2007), dan Jamaan (2008). Hal sebaliknya terjadi pada penelitian Guna dan Herawati (2010) yang menyatakan bahwa komisaris independen tidak berpengaruh terhadap manajemen laba.

Kepemilikan manajerial tidak berpengaruh terhadap integritas laporan keuangan. 
Hal ini dapat dilihat dari signifikansi sebesar 0,958 nilai ini lebih besar dari 0,05. Penelitian ini konsisten dengan Herawaty (2008), Guna dan Herawati (2010),) tetapi, tidak konsisten dengan penelitian yang dilakukan oleh Gideon (2005), Ujiyantho (2007) yang menyatakan bahwa kepemilikan manajerial berpengaruh negatif terhadap manajemen laba.

Kepemilikan Institusional tidak berpengaruh terhadap integritas laporan keuangan. Hal ini dapat dilihat dari signifikansi sebesar 0,366 nilai ini lebih besar dari 0,05. Hasil ini mendukung penelitian yang dilakukan oleh Guna dan Herawaty (2010), Ujiyantho (2007) yang menyatakan bahwa tidak terdapat pengaruh yang signifikan antara kepemilikan institusional dengan manajemen laba. Tetapi, tidak konsisten dengan penelitian Herawaty (2008), Jamaan (2008) dan susiana (2007).

Reputasi auditor dan mekanisme corporate governance (kepemilikan institusional, kepemilikan manajerial dan komisaris independen) berpengaruh secara bersama-sama (simultan) dan signifikan terhadap integritas laporan keuangan. Hasil penelitian ini mendukung hasil temuan yang dilakukan oleh Jamaan (2008), Guna dan herawati (2010). Hal sebaliknya terjadi pada penelitian Susiana (2007).

\section{REFERENSI}

Dechow, Patricia M; Richard G. Sloan; and Amy P. Sweeney. (1995). "Detecting Earnings Management", The Accounting Review, Vol. 70, No.2. pp.193- 225.

Dewi, A. A. A. Ratna.(2004). "Pengaruh Konservatisme Laporan Keuangan Terbadap Earnings Response Coefficient", Jurnal Riset Akuntansi Indonesia", Vol. 7 No. 2, Mei: 207-223.

Fala, Dwiyana A.S. (2007). "Pengaruh Konservatisma Akuntansi Terhadap Penilaian Ekuitas Perusabaan Dimoderasi oleh Good Corporate Governance", SNA X, Makasar.

Forum for Corporate Governance Indomesia (FCGI) Booklet jilid II. http://fcgi.or.id.

Ghozali, Imam. (2009). "Aplikasi Analisis Multivariate dengan Program SPSS", Badan Penerbit Universitas Diponegoro, 2009.

Gideon SB Boediono. (2005). "Kualitas Laba: Studi Pengaruh Mekanisme Corporate Governace dan Dampak Manajemen Laba dengan Menggunakan Analisis Jalur", SNA VIII, Solo.

Herawati, Vinola.(2008). "Peran Praktek Corporate Governance sebagai Moderating Variable dari Pengarub Earnings Management Terbadap Nilai Perusabaan”, SNA XI, Pontianak.

http://bizcovering.com/history/10-major-accounting-scandals/

Ikatan Akuntan Indonesia. (2004). “Standar Akuntansi Keuangan”, Salemba Empat, Jakarta.

Indriantoro, Nur dan Bambang Supomo. (2002). "Metodologi Penelitian Bisnis Untuk Akuntansi dan Manajemen", Edisi Pertama, Fakultas Ekonomi Universitas Gajah Mada., Yogyakarta.

Jama’an. (2008). "Pengaruh Corporate Governance, dan Kualitas Kantor Akuntan Publik Terbadap 
Integritas Informasi Laporan Keuangan”, Tesis Universitas Diponegoro, Semarang.

Kieso Donald E dan Jerry Weygandt.(2008). "Intermediate Accounting”, 12th edition, John Wiley and Sons.

Lennox. C.S. (2001) "Going Concern Opinion in Failing Companies: Auditor Dependence and Opinion Shopping”, Economic Dep, University of Bristol.

Lo, Eko Widodo. (2005). "Pengaruh Tingkat Kesulitan Kenangan Perusahaan Terhadap Konservatisme Akuntansi”, SNA VIII, Solo.

OECD Tim Pengkajian. (2006) "Studi Penerapan Prinsip-Prinsip OECD 2004 dalam Peraturan Bapepam Mengenai Corporate Governance”. Peraturan Bapepam, Departemen Keuangan Republik Indonesia Badan Pengawas Pasar Modal dan Lembaga Keuangan.

Pratolo, Surya. (2008) “Pengaruh Audit Manajemen, Komitmen Organisasional Manajer, Pengendalian Intern Terhadap Penerapan Prinsip-Prinsip Good Corporate Governance dan Kinerja Badan Usaha Milik Negara di Indonesia”, Jurnal Akuntansi dan Investasi vol. IX No. 1, Yogyakarta.

Shleifer, A. dan R.W. Vishny. (1997). "A Survey of Corporate Governance”, Journal of Finance, Vol.52 No.2. Juni, hal.737-783.

Susiana dan Arleen Herawaty. (2007). "Analisa Pengaruh Indepedensi, Mekanisme Corporate Governance, Kualitas Audit Terhadap Integritas Laporan Keuangan”, SNA X, Makasar.

Wibowo, Hian Ayu Ocean. "Pengarub independensi auditor, komitmen organisasi, Gaya kepemimpinan, dan pemahaman good governance Terhadap kinerja auditor. (Studi Empiris pada Kantor Akuntan Publik di Daerah Istimewa Yogyakarta)", Skripsi Universitas Islam Indonesia, Yogyakarta, 2009 